\title{
Technology for Improving Technical, Economic and Ecological Efficiency of Boiler Plants Using Physico-Chemical Correction of the Water-Fuel Emulsions Composition
}

\author{
Filipshchuk A.N., Kolbasenko O.V., Shevtsov A.P., and Dymo B.V. \\ Admiral Makarov National Shipbuilding University \\ Mykolaiv, Ukraine
}

\begin{abstract}
The aim of this work is to substantiate the possibility of increasing the technical, economic and environmental efficiency, as well as the efficiency of boilers (in terms of the intensity of corrosion processes) when burning water-fuel emulsions with the increased water and salt contents. To achieve these goals complex experimental studies were performed on the combustion of fuel oil and emulsions based on it, as well as the corrosion processes with a water content in the range from 2 to $30 \%$, and a salt content ranging from 17 to $490 \mathrm{mg} / \mathrm{dm}^{3}$ hydrodynamic homogenizer. A significant result of the studies carried out is that with a water content of $\sim 30 \%$ in the fuel gases composition, an $\mathrm{NO}_{2}: \mathrm{NO}$ ratio of 0,33 was achieved. That increased the absorption properties of gases and allowed passivation of carbon steel in sulfuric acid condensate. It also decreased the intensity of the low-temperature corrosion in the range of metal temperature of $130 \ldots 70^{\circ} \mathrm{C}$. All these made it possible to use condensation surfaces and to reduce the flue gases temperatures, to increase the efficiency of boilers, to ensure the economy of pure fuel, to increase the depth of utilization of the exhaust gases heat, and to reduce the concentration of toxic gases. The results obtained differed from those known. The significance of the results obtained lies in the fact that a technology was developed for the integrated use of the electrodialysis water resources, the waste and oil-containing waters, ensuring the operability of boilers, with a water content of emulsions of $\sim 30 \%$ and a salt content of up to $450 \mathrm{mg} / \mathrm{dm}^{3}$.
\end{abstract}

Keywords: emulsion, water content, salt content, cavitation, dispersion, activity, electrodialysis, diluate, catholyte, complex technology, corrosion, condensation boilers, efficiency, ecology.

DOI: https://doi.org/10.52254/1857-0070.2021.3-51.06

UDC: УДК 621.036.07

\section{Tehnologie pentru îmbunătățirea eficienței tehnice, economice și ecologice a centralelor termice prin corectarea fizico-chimică a compoziției emulsii apă-combustibil \\ Filipsciuk A.N., Kolbasenko O.V., Șevțov A.P., Dîmo B.V. \\ Universitatea Natională de construirea navelor amiral Makarov \\ Nikolaev, Ucraina}

Rezumat. Scopul lucrării este de a fundamenta posibilitatea creșterii eficienței tehnice, economice și de mediu, precum și a operabilității cazanelor (în ceea ce privește intensitatea proceselor de coroziune), în care emulsiile de apă-combustibil cu conținut crescut de apă și sare conținutul este ars. Pentru atingerea obiectivelor stabilite, s-au efectuat studii experimentale comprehensive ale arderii păcurii şi emulsiilor bazate pe aceasta, precum și a proceselor de coroziune, cu corecția fizico-chimică a parametrilor: conținut de apă de la 2 la $30 \%$, salinitate de la 17 la $490 \mathrm{mg} / \mathrm{dm} 3$ în timpul tratamentului de cavitație a apei într-un electrodializator cu câmp electric și tratarea rigidă de cavitație a emulsiilor într-un omogenizator hidrodinamic. Un rezultat semnificativ al cercetării este că, cu un conținut de apă de aproximativ 30\% în compoziția gazelor arse, se obține un raport NO2: NO de 0,33 , care crește proprietățile de absorbție ale dioxidului de sulf și duce la pasivarea oțelului carbonic în condensat de acid sulfuric și o scădere a intensității coroziunii la temperaturi scăzute la un nivel de $0,3 \ldots 0,12$ $\mathrm{mm} /$ an în intervalul valorilor de temperatură a metalelor de $130 \ldots 70^{\circ} \mathrm{C}$, ceea ce face posibilă utilizarea condensului suprafețelor și reduceți temperatura gazelor arse la $80 \ldots 100^{\circ} \mathrm{C}$, creșteți eficiența cazanelor auxiliare cu 10 ... 15\% și realizați economii de combustibil curat cu până la 25 ... 27\%, crescând adâncimea de utilizare a evacuarea căldurii până la $65 \%$.

Cuvinte-cheie: emulsie, conținut de apă, salinitate, cavitație, dispersie, activitate, electrodializă, diluare, catolit, tehnologie integrată, coroziune, cazane cu condensare, eficiență, ecologie.

(C) Филипщук А. Н., Колбасенко О.В., Шевцов А.П., Дымо Б.В., 2021 


\section{Технология повышения технико-экономической и экологической эффективности котельных установок физико-химической коррекцией состава водотопливных эмульсий Филипщук А.Н., Колбасенко О.В., Шевцов А.П., Дымо Б.В.}

Национальный университет кораблестроения имени адмирала Макарова Николаев, Украина

Аннотация. Целью работы является обоснование возможности повышения технико-экономической и экологической эффективности, а также работоспособности котлов (по интенсивности коррозионных процессов), в которых сжигаются водотопливные эмульсии с повышенным водосодержанием и солесодержанием. Для достижения поставленных целей проведены комплексные экспериментальные исследования горения мазута и эмульсий на его основе, а также коррозионных процессов, при физикохимической коррекции параметров: водосодержания от 2 до 30\%, солесодержания от 17 до 490 мг/дм³ при кавитационной обработке воды в электрическом поле электродиализатора и жесткой кавитационной обработке эмульсий в гидродинамическом гомогенизаторе. Существенным результатом проведенных исследований является то, что при водосодержании около $30 \%$ в составе дымовых газов достигается отношение $\mathrm{NO}_{2}: \mathrm{NO}$ на уровне 0,33 , что повышает абсорбционные свойства сернистых газов и приводит к пассивации углеродистой стали в конденсате серной кислоты и снижению интенсивности низкотемпературной коррозии до уровня 0,3...0,12 мм/год в диапазоне значений температуры металла $130 \ldots 70{ }^{\circ} \mathrm{C}$, что позволяет применить конденсационные поверхности и снизить температуры уходящих газов до $80 \ldots 100{ }^{\circ} \mathrm{C}$, повысить КПД вспомогательных котлов на $10 \ldots 15 \%$ и достичь экономии чистого топлива до $25 \ldots .27 \%$, увеличить глубину утилизации теплоты выхлопных газов до 65\%. При этом достигается снижение концентрации $\mathrm{NO}_{\mathrm{x}}$ в 3,2 раза, $\mathrm{SO}_{2}$ в 2,5 раза, $\mathrm{CO}_{2}$ в 1,4 раза и соответственно уменьшение размеров секций скрубберов. Полученные результаты отличаются от известных комплексным учетом технико-экономических и экологических параметров при обеспечении низкой интенсивности низкотемпературной коррозии. Значимость полученных результатов заключается в том, что на их основе разработана технология, которая обеспечивает комплексное использование водных ресурсов при применении электродиализных опреснителей, сточных и нефтемаслосодержащих вод, а также обеспечении работоспособности котлов при водосодержании эмульсий $\sim 30 \%$ и солесодержании до $450 \mathrm{мг} / д \mathrm{~m}^{3}$.

Ключевые слова: эмульсия, водосодержание, солесодержание, кавитация, дисперсность, активность, электродиализ, дилюат, католит, комплексная технология, коррозия, конденсационные котлы, эффективность, экология.

\section{ВВЕДЕНИЕ}

При сжигании тяжелых сернистых мазутов возникают проблемы, связанные с высоким значением выбросов токсичных ингредиентов и тепловых выбросов в атмосферу, с ростом высокотемпературной и особенно низкотемпературной коррозии, что приводит к снижению работоспособности котлов и относительно низких КПД. В котлах минимальные значения температуры стенки поверхности нагрева $t_{\text {ст }}$ выше $130{ }^{\circ} \mathrm{C}$, a температура уходящих газов находится на уровне $140 \ldots 160{ }^{\circ} \mathrm{C}$, так как вследствие интенсивной низкотемпературной сернокислотной коррозии (НTK) (англ. low temperature sulfuric acid corrosion (LTC)) в области "кислотного пика" при температуре $\mathrm{t}_{\mathrm{c \tau}} \sim 110^{\circ} \mathrm{C}$ скорость коррозии достигает 1,3 мм/год. Вследствие этого конденсационные поверхности в промышленных и утилизационных котлах не используются.

Жесткость требований мировых стандартов на выбросы вредных веществ в атмосферу и водную среду энергетическими установками вместе с проблемой роста цен на топливные ресурсы увеличивают значимость и актуальность вопросов, связанных с комплексным подходом к решению проблем эффективного использования топливноэнергетических и водных ресурсов на основе применения альтернативных топлив путем изменения их физико-химических свойств и состава, в частности впрыска воды или пара и сжигания водотопливной эмульсии.

В публикациях последних лет представлены обобщенные данные (при ссылках на сотни публикаций) о перспективности применения в качестве альтернативных топлив водотопливных эмульсий (ВТЭ) [1-14], их свойствах $[1,4], \quad$ о способах подготовки эмульсий $[1,2]$, в которых особое внимание обращается на уровень дисперсности и необходимости обеспечения стабильности получаемых эмульсий $[1,5]$. Приводятся также данные о существенном улучшении процессов горения вследствие микровзрывов капель водотопливных эмульсий [1-7,10-12], что приводит к экономии топлива, значения которых представлены в больших пределах [1,3-5,8,14], а также сведения о снижении эмиссии вредных компонентов дымовых газов $[1-4,6,8,10,15]$. 
Преимущества

применения водотопливных эмульсий по сравнению с традиционным нефтяным топливом определяется по пяти критериям (снижение

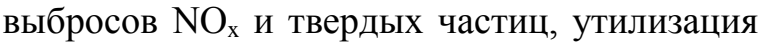
нефтемаслосодержащих вод, величины водосодержания, расходы эмульсий и чистого топлива в них $[1,6,11])$. По данным [1,3$5,10,14]$ экономия топлива меняется в пределах от 13,56 \% при водосодержании $8 \%$ до 22,24 \% при водосодержании около $15 \%$. Согласно данным [14] с увеличением водосодержания $\mathrm{W}^{\mathrm{r}}$ водотопливных эмульсий вплоть до $40 \%$ наблюдается снижение расхода чистого топлива. Расход эмульсии вплоть до водосодержания $\mathrm{W}^{\mathrm{r}}=25 \%$ практически равен расходу сухого топлива при $\mathrm{W}^{\mathrm{r}}=0 \%$. Экономия чистого топлива составляет около 25\% при водосодержании эмульсии $\mathrm{W}^{\mathrm{r}}=25 \%$.

В публикациях отмечается одновременное снижение $\mathrm{NO}_{x}$ и твердых частиц, а также $\mathrm{CO}$, $\mathrm{SO}_{2}, \quad \mathrm{H}_{2} \mathrm{~S}$ и углеводородов $\mathrm{C}_{\mathrm{x}} \mathrm{H}_{\mathrm{y}}$ путем управления режимами работы котлов $[1,3]$. Присутствие воды в эмульсии приводит к снижению температуры пламени и изменению состава реагентов, сопровождающегося увеличением концентрации радикалов $\mathrm{OH}^{-}$, контролирующих скорость образования $\mathrm{NO}_{\mathrm{x}}$ $[1,6,16,17]$. В частности для промышленных котлов важно значение избытка воздуха и влажности воздуха $[1,15,18]$. Подача воды в реакционную зону в основном осуществляется двумя способами: путем впрыскивания в воздух или в ядро факела пара или воды и путем применения водотопливных эмульсий $[1-4,6,8,10,15,19$ 21].

Несмотря на большое количество публикаций о положительном влиянии микровзрывов капель эмульсии на процесс горения вследствие их вторичного распыливания и усиления турбулентности в факеле [1-9], остается много нерешенных вопросов [1,2], т.к. процесс микровзрыва влияет на физику горения и его химическую кинетику [6,11]. Свободный радикал $\mathrm{OH}^{-}$, имеющий высокую химическую активность, в процессе горения вступает во взаимодействие с углеводородами. Скорость реакции горения пропорциональна концентрации гидроксила $\mathrm{OH}^{-}[1-5,16,17,20]$.
Поэтому важным фактором улучшения процесса горения эмульсий является предварительное накопление свободных радикалов при их подготовке.

Подготовка эмульсий осуществляется различными способами при использовании различных конструкций гомогенизаторов: механических, имеющих систему роторстатор $[1,9,10]$, эмульгирование с помощью мембран (в частности премикс-мембран) и микроканальных эмульгаторов [9], а также ультразвуковых гомогенизаторов. По данным $[1,2]$ производится подготовка эмульсий в промышленных масштабах без применения каких-либо поверхностно-активных веществ. В [1] представлены данные о конструкции гомогенизатора производительностью 20 т/ч со скоростью вращения ротора 4000 об/мин. При подготовке эмульсий основное внимание уделяется ее дисперсности (размер капель, температура, время перемешивания, тип гомогенизатора), а также стабильности полученных эмульсий $[1,5,13]$. По мнению $[1,13]$ эмульсия считается стабильной, если она сохраняется без разделения фаз в течение 5 суток и более при диаметре капель воды $2 . . .3$ мкм.

В [22] при сжигании водотопливной эмульсии, которая названа "топливо экологически чистое дизельное" (выпускается Кременчугским НПЗ (Украина)), с содержанием воды $12,3 \%, 19,4 \%, 23,2 \%$, $31,2 \%$ по массе, приготовленной с тремя уровнями диспергации: 0 - грубая диспергация (средний диаметр капель воды в ТЭД 8...9 мкм), 1 - улучшенная диспергация (средний диаметр капель воды в ТЭД 5...6 мкм), 2 - тонкая диспергация (средний диаметр капель воды в ТЭД 1...3 мкм). Более тонкая диспергация ТЭД снижает концентрацию в выхлопных газах оксида углерода на $20 \ldots 30 \quad \ldots$ ppm и дымность отработанных газов на $2 \%$. Поэтому необходимо учитывать влияние уровня кавитационной обработки эмульсии на повышение экологической эффективности.

В [10] представлены данные о сравнительных испытаниях сжигания тяжелого мазута и мазутной эмульсии с использованием до $10 \%$ сточной воды, согласно которым повышается эффективность работы котла до $10 \ldots 33$ \% и сокращение расхода топлива на 5 ... $31 \%$. При этом выбросы $\mathrm{SO}_{x}$ снизились на $3,3 \ldots$ 
$7,1 \%$, твердых частиц на $41 \ldots 85 \%$, СО на 89

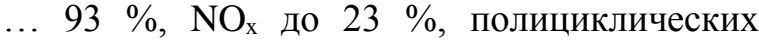
ароматических углеводородов и в частности бензо(а)пирена на 37,7 и $61,8 \quad \%$ соответственно. Применение сточных вод [9] до $20 \%$ эмульсии обеспечит не только безопасное удаление промышленных сточных вод с содержанием до 440 мг/дм ${ }^{3}$ нефтеостатков, но и экономии энергии до $13 \%$.

Способы очистки уходящих газов от токсичных соединений, представлены во многих публикациях например [1-4,6,8,23,24]. По мнению специалистов фирмы MAN $[23,24]$ требования по снижению уровня эмиссии $\mathrm{SO}_{\mathrm{x}}, \mathrm{NO}_{\mathrm{x}}$ можно выполнить с помощью технологий: использования водотопливной эмульсии, увлажнения наддувочного воздуха, рециркуляции выхлопных газов, селективного каталитического снижение эмиссии $\mathrm{NO}_{\mathrm{x}}$.

К радикальным и достаточно простым способам снижения содержания сернистых соединений и оксидов азота в дымовых газах энергетических установок является очистка выхлопных газов с помощью скрубберных технологий $[23,25,26]$. Испытания системы $\mathrm{CSNO}_{\mathrm{x}}$ [23] показали, что при значениях содержания токсичных веществ на выходе из главного котла паропроизводительностью 60 т/ч концентрации $\mathrm{SO}_{2}$ на уровне $669,3 \mathrm{ppm}$, $\mathrm{NO}_{x}$ на уровне $158,5 \mathrm{ppm}$ и $\mathrm{CO}_{2}$ на уровне $5,16 \%$ на выходе из скруббера содержание этих же ингредиентов составило: 47,4 ppm $\mathrm{SO}_{2}, 28,2 \mathrm{ppm} \quad \mathrm{NO}_{\mathrm{x}} \quad 1,32 \% \mathrm{CO}_{2}$. То есть эмиссия основных вредных веществ снизилась: $\mathrm{SO}_{2}$ на $92,9 \%, \mathrm{NO}_{x}$ на $82,2 \%, \mathrm{CO}_{2}$ на $74,4 \%$. Указанная эффективность использования скрубберной технологии принята за основу при оценке применения мокрых скрубберов в разработанной комплексной технологии.

Как известно из теории физикохимических процессов сернокислотного производства по нитрозному механизму [27], обеспечение в потоке газов эквимолярного или близкого к нему отношения $\mathrm{NO}_{2}: \mathrm{NO}$ приводит к соответствующему содержанию $\mathrm{N}_{2} \mathrm{O}_{3}$ в нитрозе при температурах $80 \ldots 130{ }^{\circ} \mathrm{C}$ (что соответствует температурам процессов на низкотемпературных поверхностях нагрева котлов при конденсации паров серной кислоты). При концентрации $\mathrm{H}_{2} \mathrm{SO}_{4}$ около $57 \%$ происходит резкий рост интенсивности абсорбции $\mathrm{SO}_{2}$ (в $6 \ldots 8$ раз).
Если обеспечить такие условия при сжигании водотопливной эмульсии, то соответственно возможно интенсифицировать процессы абсорбции и уменьшить размеры скрубберов $[23,25,26]$. Кроме того, необходимо отметить, что при нитрозном производстве $\mathrm{H}_{2} \mathrm{SO}_{4}$ применяются углеродистые стали (трубопроводы, теплообменники, цистерны для хранения и перевозки), т.к. после 20 часов под влиянием оксидов азота происходит пассивация поверхности металла.

Проведенные исследования и накопленный эксплуатационный опыт [1,3$5,8,14,19-21,28]$ показали, что сжигание эмульсии в котлах обеспечивает: полную надежность сжигания мазута с содержанием в нем воды до $50 \%$; высокую экономичность сжигания мазута при его обводнении до $25 \ldots 30 \%$; повышение КПД котельной установки и соответственно снижение расхода сухой чистой массы топлива. При сжигании водомазутной эмульсии (ВМЭ) на основе тяжелого мазута с водосодержанием $30 \%$ при $\alpha \sim 1,3 \quad[16,17,20,21]$, вследствие микровзрывов ее капель интенсивность загрязнения и коррозии в котлах [21] существенным образом снижаются, а периодичность между очистками увеличивается в 2...3 раза (до 2,5 тыс.ч). Причем, после двухгодичной эксплуатации котла на трубах экономайзера при низких температурах металла наблюдается переход от язвенной коррозии к незначительной сплошной НТК.

Практически отсутствуют данные о интенсивности коррозионных процессов в котлах при сжигании водотопливных эмульсий: не найдены публикации о интенсивности высокотемпературной коррозии, численные значения скорости низкотемпературной коррозии представлены в [29,30]. В публикациях последних лет, в которых обобщено большое количество ссылок, представлены только данные: о механизме процессов электрохимической коррозии $\quad[31,32,33]$, в которых рассматривается влияние $\mathrm{Cl}^{-}, \mathrm{SO}_{4}{ }^{2-}, \mathrm{NO}_{3}{ }^{-}$без учета влияния сжигания водотопливной эмульсии; влияние присадок как в металл, так и в растворы и газы [34,35], влияющих на интенсивность коррозии; о подходах к определению температуры точки росы паров серной кислоты [32,36,37]; о мерах борьбы с последствиями коррозии [35,38], в которых предлагается замена углеродистой стали на 
более коррозионностойкую нержавеющую сталь или повышение температуры поверхности нагрева выше температуры точки росы паров серной кислоты.

Анализ представленных в литературных источниках [31-37,39] данных показывает, что следует рассматривать два раздельно действующих механизма высокотемпературной коррозии:

- ванадиевого - под влиянием соединений ванадия, (особенно ванадил-ванадата натрия) $[39,40]$;

- сульфатного - под влиянием хлоридов, $\mathrm{SO}_{2}, \mathrm{O}_{2}$ и сульфатов, которые появляются в отложениях вследствие преобразования хлоридов в сульфаты в течение $\sim 3$ часов в отложениях. По мнению [39,40] сульфатный механизм высокотемпературной коррозии имеет более существенное значение, чем первый (ванадиевый). В публикациях представлено мало сведений об общем влиянии натрия и хлоридов при сжигании мазутов.

Наиболее перспективными следует считать комплексные технологии, как обработки топлива, так и воды перед их смешением [19,41]. Близкой к предлагаемой в работе системы подготовки пресной воды и самой водотопливной эмульсии является система подготовки водотопливной эмульсии с электрохимической обработкой воды в электролизере [41].

C нашей точки зрения расхождение в значениях технико-экономических и экологических показателей сжигания водотопливной эмульсии объясняется разными методами подготовки воды и водотопливной эмульсии, отсутствием учета уровня активности воды и водотопливной эмульсии непосредственно перед сжиганием, а также разным качеством (солесодержанием) пресной воды, которая используется для подготовки водотопливной эмульсии с разным водосодержанием.

Описание нерешенных частей в проблеме. Отсутствуют конкретные требования к качеству пресной воды, показатели качества которой не регламентированы (особенно по значению ее солесодержания). Отсутствуют данные по интенсивности высокотемпературной и низкотемпературной сернокислотной коррозии при сжигании водомазутной эмульсии с разным водосодержанием и солесодержанием. Отсутствуют разработки конструктивных схем промышленных и утилизационных котельных установок с использованием конденсационных поверхностей нагрева, изготовленных из углеродистой стали при сжигании сернистых водомазутных эмульсий.

В публикациях не рассматривается возможность создания комплексной технологии эффективного использования топливно-энергетических и водных ресурсов с разным солесодержанием (солоноватых, соленых и морских вод) при сжигании водотопливных эмульсий при одновременном обеспечении работоспособности элементов котлов.

Формулировка цели и задач исследований. Целью работы является исследование возможностей повышения технико-экономической и экологической эффективности, а также работоспособности (по интенсивности коррозионных процессов) котлов, в которых сжигаются водотопливные эмульсии с повышенным водосодержанием и солесодержанием с применением физикохимической коррекции их состава, что обеспечит создание комплексной технологии для выполнения указанных целей.

\section{МЕТОДЫ, РЕЗУЛЬТАТЫ И ОБСУЖДЕНИЕ}

Методы исследования. Для достоверности оценки влияния разных факторов (коэффициента избытка воздуха $\alpha$, солесодержания воды, уровня кавитационной обработки воды, водосодержания $\mathrm{W}^{\mathrm{r}}$ и солесодержания водотопливных эмульсий) исследования были проведены на экспериментальной установке, что обеспечивает постоянство параметров горения мазута и водотопливной эмульсии, а также процессов коррозии. Интенсивность коррозийных процессов определялась по разнице масс металла при установке охлаждаемых образцов труб в газоход: при температуре газов $\sim 1000 \quad{ }^{\circ} \mathrm{C}$ при исследованиях высокотемпературной коррозии и $\sim 200{ }^{\circ} \mathrm{C}$ при исследованиях низкотемпературной коррозии. $\mathrm{C}$ целью сравнения коррозийной стойкости марок сталей использовались образцы труб из углеродистой стали 20 и нержавеющий стали $1 \mathrm{X18H10T,} \mathrm{т.к.} \mathrm{они} \mathrm{находятся} \mathrm{на}$ противоположных сторонах диапазона коррозийной стойкости сталей, которые используются в энергетических установках. 
Bce серии опытов проведены при использовании одной пробы мазута M40 с содержанием серы $\mathrm{S}^{\mathrm{r}}=1,8 \%$, что обеспечило одинаковую концентрацию ванадия в топливе на уровне $0,0014 \%$ и предоставило возможность четкого определения влияния содержания $\mathrm{NaCl}$ в воде и значение допустимого солесодержания водотопливных эмульсий на интенсивность коррозийных процессов. Показатель уровня кавитационной обработки эмульсий оценивался по значению $\mathrm{pH}$ (достигнуто $8,0 \ldots 8,5)$ и диаметру капель воды (1...2 мкм). Контроль качества горения мазута и водотопливной эмульсий на его основе, значений выбросов $\mathrm{NO}_{x}, \mathrm{SO}_{2}, \mathrm{CO}_{2}$ контролировались с помощью хроматографа "Газохром-3101" и ОКСИ-5М (относительная погрешность на уровне $\pm 5 \%$ ). Постоянство расхода топлива (погрешность измерения $\pm 1 \%)$ в течение опыта контролировалось по стабильности температуры газов на выходе из камеры сгорания экспериментальной установки на уровне $1200{ }^{\circ} \mathrm{C}$ с помощью специальной экранированной отсосной термопары. Точность измерений температур $\pm 5^{\circ} \mathrm{C}$. Диапазон изменения солесодержания водотопливной эмульсии составлял $17 \ldots 490$ мг/дм ${ }^{3}$, водосодержание менялось от 2 до $30 \%$.

Система подготовки водотопливной эмульсии состоит с двух контуров: предварительной кавитационноциркуляционной подготовки и поддержки полученного ее качества непосредственно перед горелкой. В первом контуре осуществляется сильная (жесткая) кавитационная обработка эмульсии по циркуляционной схеме с гидродинамическим гомогенизатором, в котором осуществляется энергичная закрутка потока при высоком давлении тангенциально расположенными лопатками с острыми кромками и последующим направлением потока на донышко камеры гомогенизатора, где за счет гидроудара образуется мелкодисперсная структура эмульсии. Во втором контуре поддерживался постоянным достигнутый уровень активности эмульсии за счет многократной циркуляции с помощью шестеренчатого насоса с отводом необходимого расхода эмульсии через дозатор расхода на ротационную горелку.
Результаты и обсуждение. При кавитационно-циркуляционной подготовке водотопливной эмульсии в течение $10 \ldots 15$ мин стабилизируется значения $\mathrm{pH}$, которое характеризует содержание ионов $\mathrm{H}^{+}$и $\mathrm{OH}^{-}$в воде и эмульсии перед сжиганием. Если сохранять готовую водотопливную эмульсию, то наблюдается потеря активности воды в подготовленной водотопливной эмульсии в течение $\sim 300$ мин при сохранении стабильности дисперсности в течение двух недель (рис.1).

На основе энергетических балансов при одинаковых температурах газов на выходе из камеры сгорания экспериментальной установки на уровне $1200{ }^{\circ} \mathrm{C}$ при сжигании мазута и водомазутных эмульсий с разным водосодержанием (от 2 до 30 \%) получены зависимости (рис.2) расходов водомазутных эмульсий (кривая 1) и чистого топлива в них (кривая 2) (данные Национального университета кораблестроения (НУК, Украина)) и проведено сравнение с аналогичными данными Днепровского Национального университета имени Олеся Гончара (ДНУ, Украина) [14] (соответственно кривые 3 и 4), которые получены при сжигании водотопливных эмульсий при водосодержании до $40 \%$ на основе печного топлива в котле НИИСТУ-5 при поддержке постоянного значения интегральной температуры факела на уровне $1325{ }^{\circ} \mathrm{C}$. Установлено, что экономия чистого топлива достигает $\sim 25 \quad \%$ при сжигании водотопливных эмульсий в котлах с водосодержанием 25...27 \%. На основании этих данных (рис.3) представлены сравнения экономичности котлов с учетом уровня активности получаемых эмульсий. При обеспечении максимального уровня активности кавитационной подготовки эмульсий (кривая 1) получены значения экономии топлива на $\sim 12 \%$ выше по сравнению с режимом работы, когда отключен первый контур кавитационноциркуляционной обработки (кривая 3), что указывает на необходимость обеспечения максимального уровня активности эмульсий непосредственно перед сжиганием. Зависимость значения экономичности сжигания водотопливных эмульсий на основе печного топлива (данные ДНУ) (кривая 2) находится между кривыми 1 и 3. 


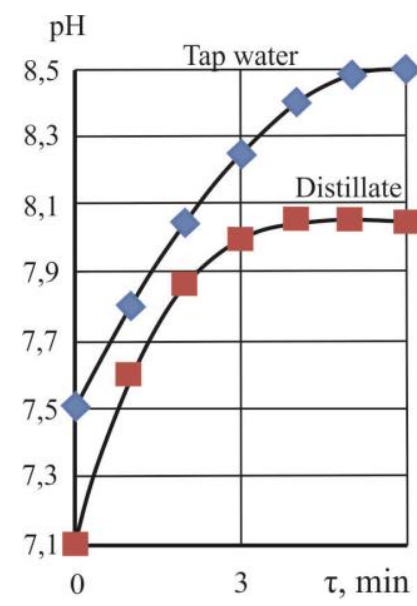

Активация воды при кавитационной подготовке водомазутной эмульсии / Activation of water during cavitation preparation of a oil-water emulsion

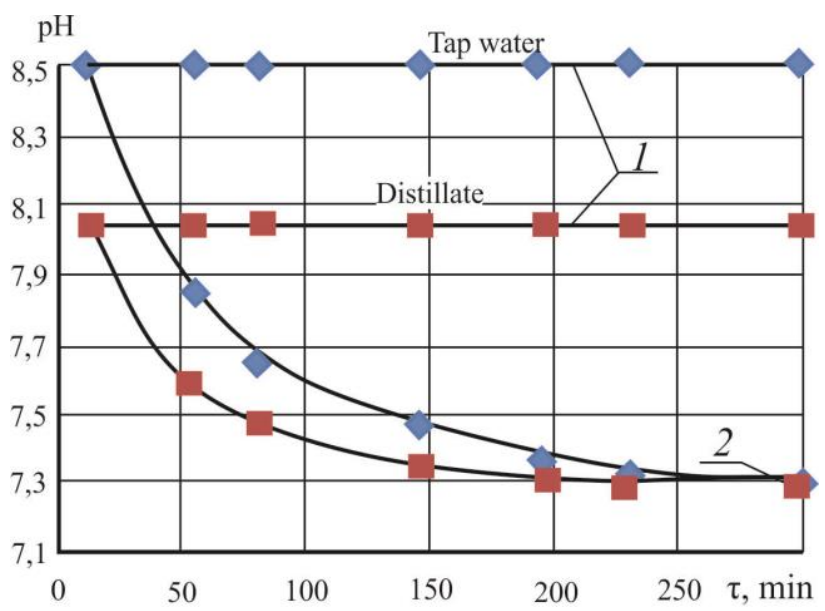

Время потери активности воды в подготовленной водомазутной эмульсии / The time of loss of water activity in the prepared oilwater emulsion

1 - поддержание постоянного значения активности в водотопливной эмульсии; 2 - стабильное состояние водомазутной эмульсии (отсутствие коагуляции капель воды в течение месяца) но без активности по рН

Рис.1 - Активность воды в эмульсии при кавитационно-циркуляционной подготовке. ${ }^{1}$

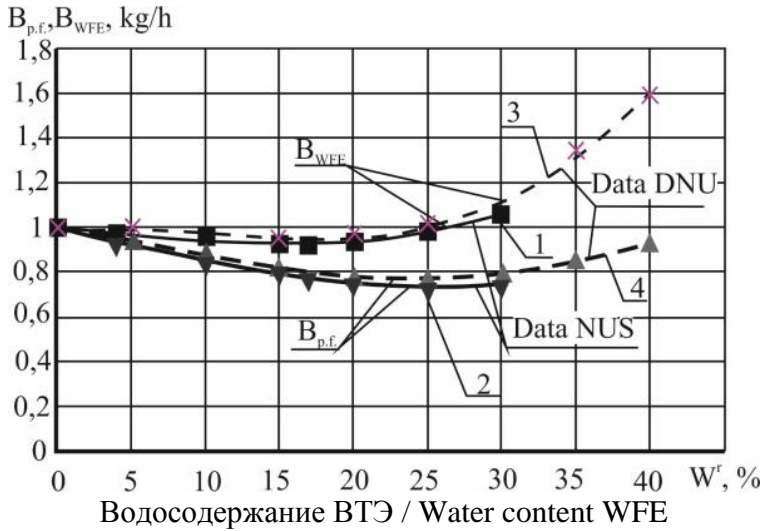

Рис. 2. Сравнение данных по расходам водотопливных эмульсий ВшғE И чистого топлива В.f В зависимости от водосодержания $\mathrm{W}^{\mathrm{r}}$ водотопливных эмульсий. ${ }^{2}$

Уровень влияния физико-химической коррекции состава (солесодержания и водосодержания) на ход электрохимических процессов низко- и высокотемпературной коррозии, которые обусловливают работоспособность элементов энергетических установок и определяют возможности повышения технико-экономических показателей, был определен по данным исследований интенсивности коррозионных процессов. Проведенные экспериментальные исследования кинетики коррозии в течение 2 , $4,8,12$ часов эксперимента позволили на основе полученных апроксимационных уравнений прогнозировать развитие коррозии 1,2,3 Appendix 1

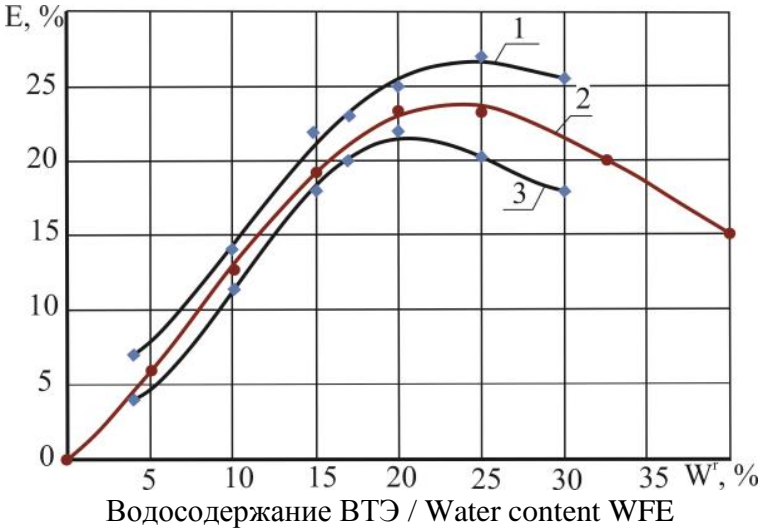

Рис. 3. Экономия чистого топлива В.f В эмульсиях в зависимости от их водосодержания $\mathrm{W}^{\mathrm{r}}{ }^{3}$

времени воздействия потока газов $\tau$. Адекватность модели подтверждена результатами 100-часовых опытов. С помощью принятой математической модели процесса коррозии при использовании программного пакета Statgraphics Centurion XV получены зависимости скорости коррозии от температуры стенки за 100 часов, а также с учетом периодичности очистки через 1000 часов при сжигании мазута и 3000 часов при сжигании водомазутных эмульсий (рис.4 $a, б$ ).

На рис.4,a представлены полученные зависимости скорости высокотемпературной коррозии стали 20 от температуры стенки в пределах $460 . .540{ }^{\circ} \mathrm{C}$ и стали $1 \mathrm{X} 18 \mathrm{H} 10 \mathrm{~T}$ 
(рис.4,б) в пределах $540 \ldots 660 \quad{ }^{\circ} \mathrm{C}:$ при сжигании мазута M40 при $\alpha=1,01$ (кривая 1), $\alpha=1,025$ (кривая 2), $\alpha=1,05$ (кривая 3), $\alpha=$ 1,5 (кривая 4) и при сжигании водомазутной эмульсий на его основе при $\alpha=1,5$ с

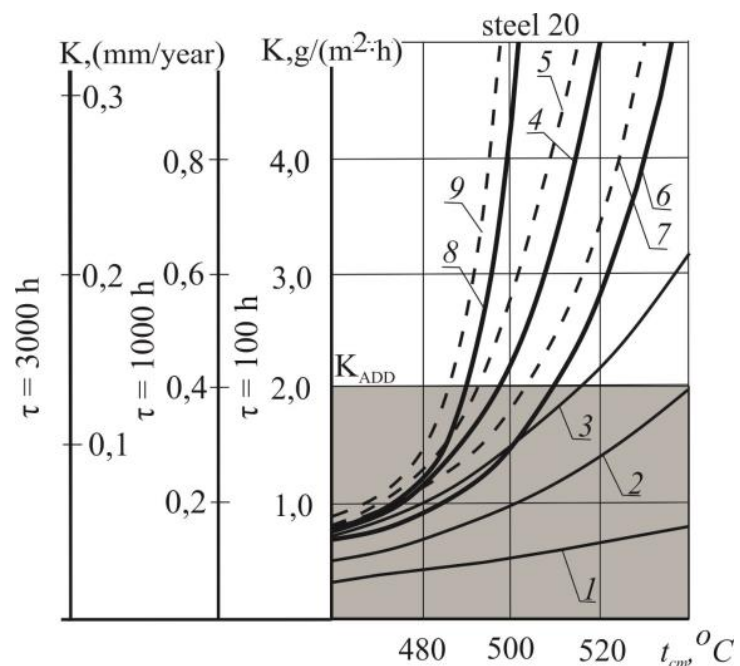

Температура стенуки металла / Metal wall temperature солесодержанием 17,0 мг/дм ${ }^{3}$ (кривая 6) и при солесодержании 490 мг/дм ${ }^{3}$ (кривая 8), при $\alpha$ $=3,0$ при солесодержании 17,0 мг/дм ${ }^{3}$ (кривая 7) и при солесодержании 490 мг/дм ${ }^{3}$ (кривая 9).

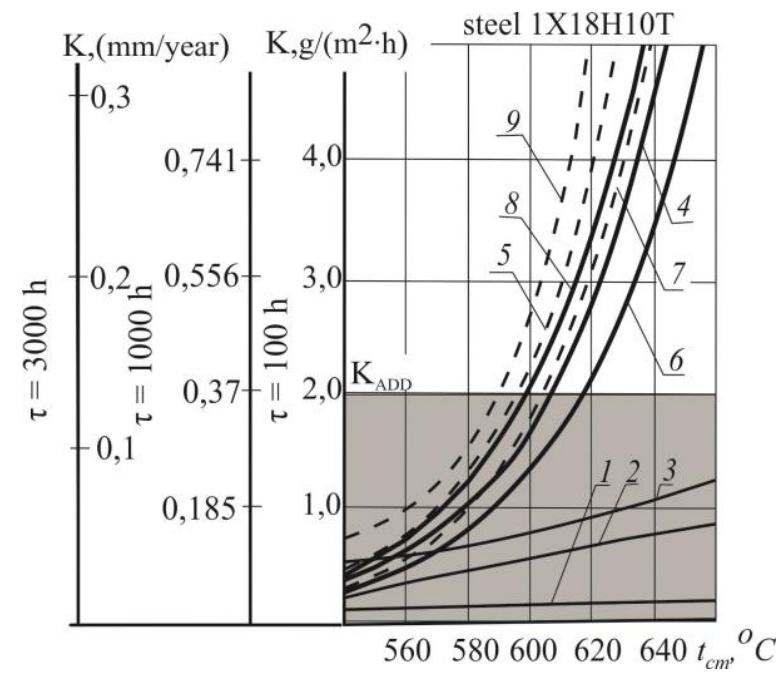

Температура стенуки металла / Metal wall temperature

$\mathrm{K}_{\mathrm{ADD}}$ - допустимое значение скорости высокотемпературной коррозии / permissible value of the rate of high-temperature corrosion.

Рис. 4. Зависимости скорости высокотемпературной коррозии сталей $\mathrm{K}$ при времени воздействия потока газов $\tau$ равном 100, 1000 и 3000 ч. ${ }^{4}$

Исследования высокотемпературной коррозии показали, что с уменьшением солесодержания водомазутной эмульсий в указанных пределах значений $t_{\text {ст }}$ скорость высокотемпературной коррозии понижается в 1,6 раза для стали $1 \mathrm{X} 18 \mathrm{H} 10 \mathrm{~T}$ и в 3 раза для стали 20 в пределах солесодержания $17 \ldots 180$ мг/дм³ ${ }^{3}$ Поэтому для обеих марок сталей для обеспечения допустимых значений скорости высокотемпературной коррозии $(0,3 \ldots 0,25$ мм/год) рекомендуется солесодержание водомазутных эмульсий ниже 180 мг/дм ${ }^{3}$. В этом случае обеспечивается ресурс работы поверхности нагрева около 100 тыс. ч.

При увеличении солесодержания водомазутных эмульсий в пределах $17,0 \ldots 490$ мг/дм ${ }^{3}$ скорость низкотемпературной коррозии (рис. 5) находится на уровне $0,3 \ldots 0,12 \mathrm{мm} /$ год при температурах стенки в пределах $70 \ldots 130{ }^{\circ} \mathrm{C}$, что ниже допустимого уровня коррозии $K_{\mathrm{ADD}}$ при воздействия потока газов даже в течении времени $\tau=100$ ч.

Следовательно, повышение солесодержания мало влияет на скорость низкотемпературной коррозии вследствие пассивации поверхности углеродистой стали оксидами азота $[30,42]$ и поэтому допустимое солесодержание водомазутных эмульсий при обеспечении $K_{\mathrm{ADD}}$ на уровне $0,2 \ldots 0,3$ мм/год необходимо определять по интенсивности высокотемпературной коррозии. Эти зависимости (рис. 5) дают возможность определять минимальные значения $t_{\text {cт }}$ при сжигании водомазутных эмульсий с водосодержанием $\mathrm{W}^{\mathrm{r}}$ на уровне $30 \%$ при конкретных значениях солесодержания и принять решение о возможности применения конденсационных поверхностей при расширении значений $t_{\text {ст }}$ от $130{ }^{\circ} \mathrm{C}$ при сжигании мазута до $70{ }^{\circ} \mathrm{C}$ при сжигании водомазутных эмульсий с водосодержанием $\mathrm{W}^{\mathrm{r}}=30 \%$ при обеспечении допустимой скорости коррозии $K_{\mathrm{ADD}}$. Сжигание водомазутных эмульсий с водосодержанием $\sim 30 \%$ и солесодержанием до $180 \mathrm{mг} /$ дм $^{3}$ позволяют повысить максимально допустимые значения температуры стенки $t_{\text {ст }}$ для стали 20 на $10 \ldots 15{ }^{\circ} \mathrm{C}$ и стали $1 \mathrm{X} 18 \mathrm{H} 10 \mathrm{~T}$ на $15 \ldots 20{ }^{\circ} \mathrm{C}$, при обеспечении допустимой скорости коррозии $K_{\text {доп. }}$

${ }^{4}$ Appendix 1 


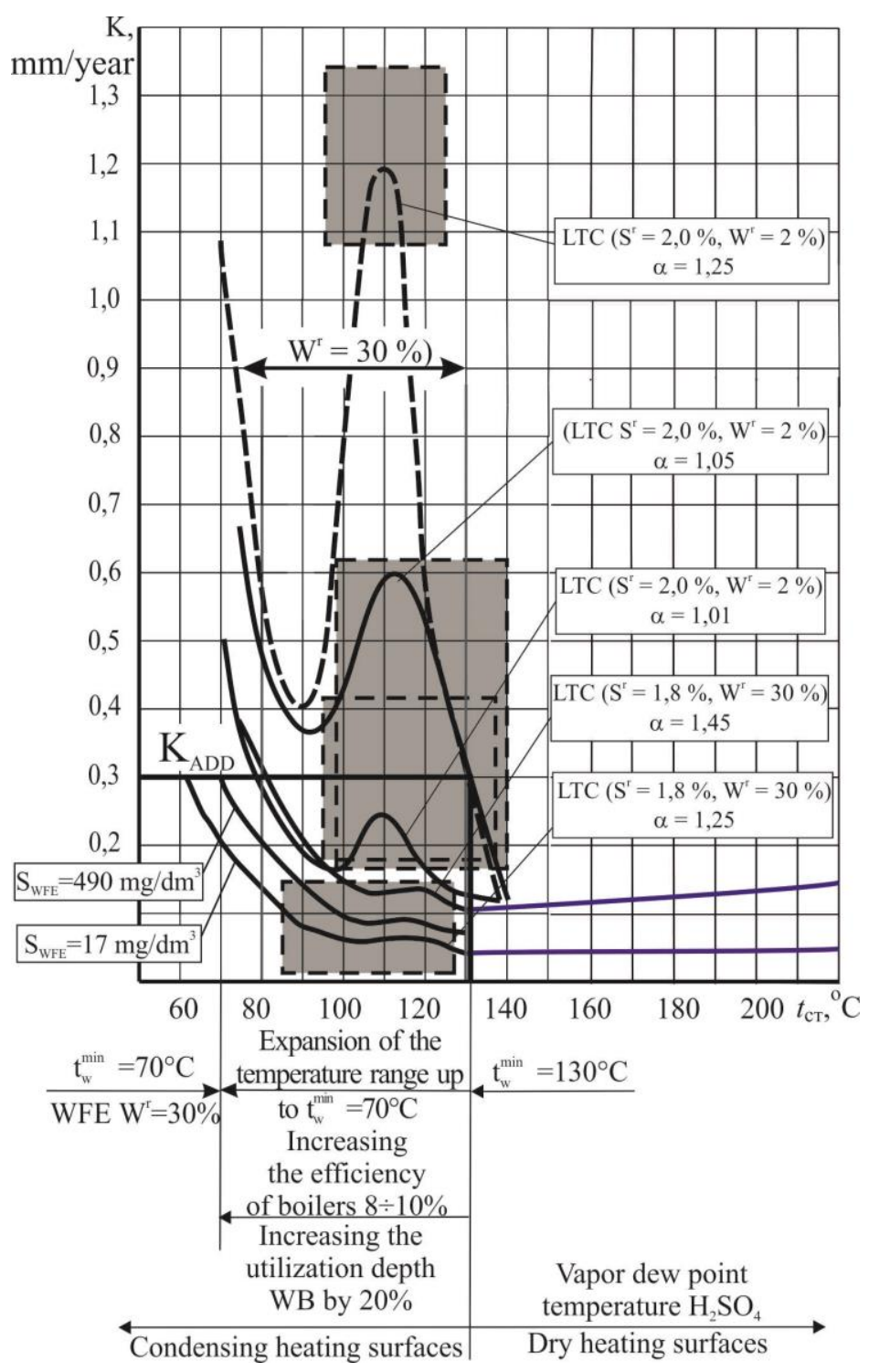

Рис. 5. Зависимости скорости низкотемпературной коррозии К стали 20 от температуры металла $t_{\text {ст }}$ (при $\tau=100$ часов). ${ }^{5}$

В связи с низкими скоростями низкотемпературной коррозии (рис. 5) и появлением возможности установки конденсационных поверхностей с температурами стенки $t_{\text {ст }}$ в пределах $130 \ldots 70$ ${ }^{\circ} \mathrm{C}$ (которые ниже температуры точки росы паров серной кислоты) при сжигании водомазутных эмульсий с водосодержанием $\mathrm{W}^{\mathrm{r}}$ на уровне $30 \%$ и с солесодержанием от 17 до 490 мг/дм ${ }^{3}$ разработаны конструктивные схемы промышленных (отопительных) и утилизационных котлов.

Базовым вариантом для сравнения принята конструкция котла при сжигании мазута, в котором используются только сухие конвективные поверхности при температурах стенки выше $130{ }^{\circ} \mathrm{C}$. В этом случае температура уходящих газов $\vartheta_{\mathrm{yx}} \geq 140 \ldots 160^{\circ} \mathrm{C}, \quad$ КПД промышленных (отопительных) котлов находится на уровне $\eta_{\text {пк }}=80 \ldots 85 \%$.

При сжигании водотопливной эмульсии с водосодержанием $\quad 30 \% \quad$ появляется возможность установки конденсационной поверхности (экономайзер, воздухоподогреватель) с температурой стенки до $70{ }^{\circ} \mathrm{C}$, что обеспечивает конденсацию паров $\mathrm{H}_{2} \mathrm{SO}_{4}$ и $\mathrm{H}_{2} \mathrm{O}$. Поэтому температура уходящих газов снижается до $\vartheta_{\text {ух }}=90^{\circ} \mathrm{C}$, а КПД котла возрастает до $\eta_{\text {пк }}=90 . .95 \%$. Эта поверхность нагрева изготавливается из углеродистой стали

\section{${ }^{5}$ Appendix 1}


благодаря пассивации металла оксидами азота.

При подаче воды из конденсатного бака или использовании воздухоподогревателя с температурами сред $50{ }^{\circ} \mathrm{C}$ и ниже (эта поверхность выполняется из нержавеющей кислотоустойчивой стали). Тогда температура уходящих газов снижается до $\vartheta_{\text {ух }}=60 . . .70^{\circ} \mathrm{C}$, что обеспечивает повышение КПД вспомогательных котлов до $\eta_{\text {пк }}=95 . . .99 \%$.

При использовании скрубберных технологий, когда необходимо существенно снизить уровень выбросов токсичных веществ, вместо поверхности из нержавеющей стали возможна установка теплообменника на выходе из мокрого скруббера, при доведении орошаемого раствора католита до $\mathrm{pH} 6,5 \ldots 7,0$, что позволяет повысить КПД котла выше 100\% (при его определении по низшей теплоте сгорания). В этом случае температура уходящих газов $\vartheta_{\text {ух }}=30 \ldots 40^{\circ} \mathrm{C}$.

Повышение глубины утилизации теплоты выхлопных газов до $65 \%$ в утилизационных котлах когенерационных установок обеспечивается также за счет установки конденсационных

(экономайзеров, секции

поверхностей, водоснабжения), что приведет к уменьшению уровня тепловых выбросов в 1,6 раза.

На основе проведенных научных исследований разработана технология комплексного использования топливноэнергетических и водных ресурсов при использовании электродиализной обработки воды, блок-схема которой представлена на рис. 6. Отличительной особенностью этой технологии является применение кавитационной обработки разного уровня интенсивности на всех этапах предварительной подготовки пресной воды, топлива и нефтемаслосодержащих вод перед смешением в кавитаторе. Легкая (мягкая) кавитационная обработка морской или соленой воды перед первым и вторым модулями электродиализной установки создает в воде большие деформированные пузырьки, которые обеспечивают их полировальное действие (а не кавитационное разрушение поверхности мембран)

[21].

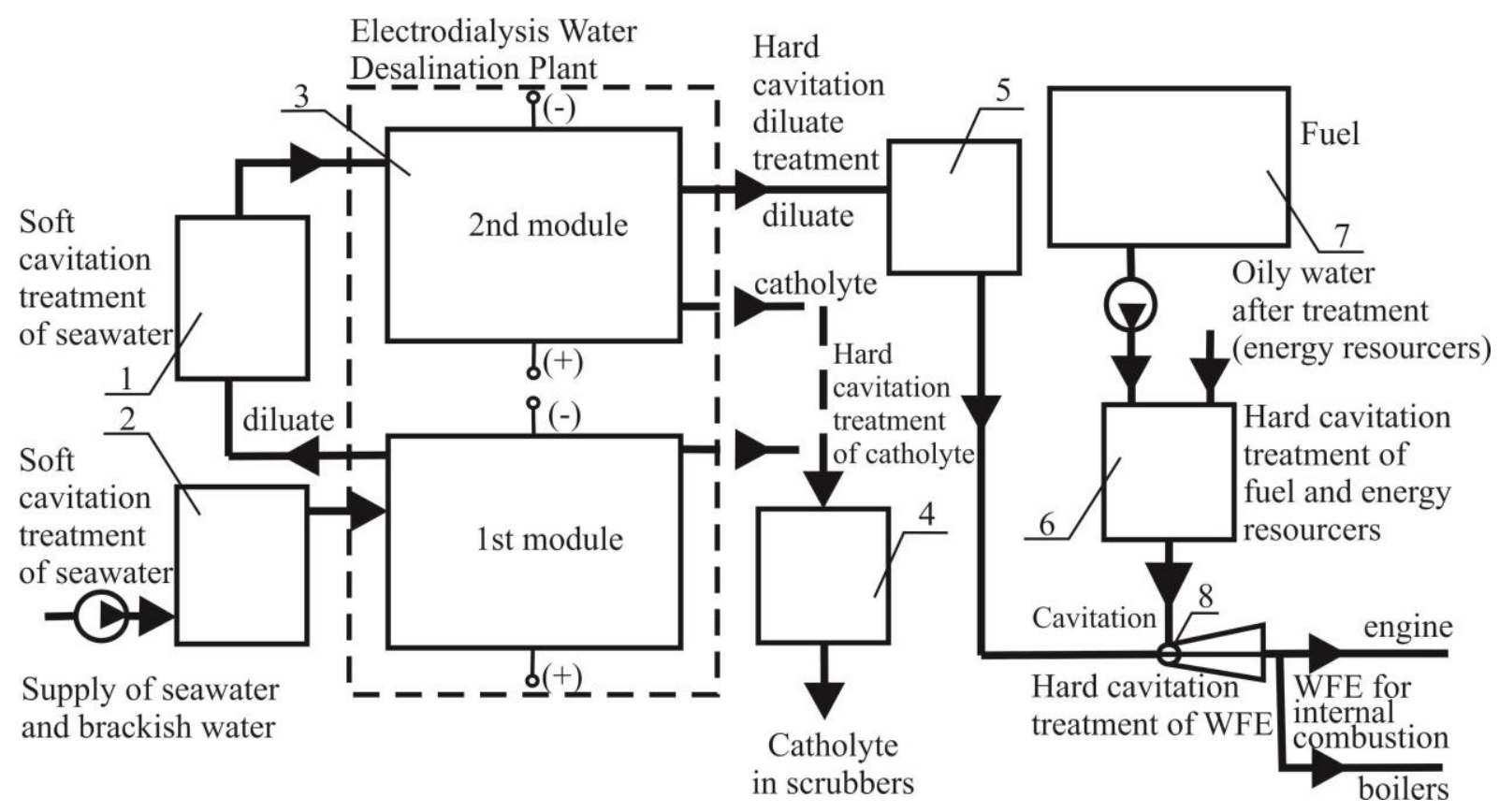

1,2 - блок-схема легкой кавитационной обработки воды, 3 - электродиализная водоопреснительная установка, 4, 5, 6 - блок-схема тяжелой кавитационной обработки воды и топлива, 7 - топливная цистерна, 8 - кавитатор (гомогенизатор).

Рис. 6. Блок-схема технологии процесса комплексного использования топливо-энергетических и водных ресурсов. ${ }^{6}$ 
Католит первого и второго модулей проходит жесткую кавитационную обработку, что повышает его абсорбционные свойства, а затем подается на орошение скрубберов и циклонов. Обессоленный в двух модулях дилюат также подвергается жесткой кавитационной обработке и подается в гомогенизатор. Подогретое до $90{ }^{\circ} \mathrm{C}$ топливо, на основе которого готовится водотопливная эмульсия поступает в блок жесткой кавитационной обработки, в который подводятся нефтемаслосодержащие воды, которые предварительно обрабатываются с целью уменьшения их солесодержания. В гомогенизаторе проводится завершающая жесткая кавитационная обработка водомазутной эмульсии для поддержания предварительно достигнутого необходимого уровня концентрации реакционно-активных свободных электронов и радикалов воды и топлива (за счет их жесткой кавитационной обработки), что обеспечивает максимальную активность водомазутной эмульсии перед непосредственной подачей к форсункам дизелей и котлов.

Такая технология подготовки водомазутной эмульсии не требует существенной реконструкции топливной системы для двигателей внутреннего сгорания и котлов, учитывая, что в современных системах топливоподготовки используется установка гомогенизаторов.

В технологии предусмотрено использование воды после продувки котлов и обработанных сточных вод с щелочными свойствами, а также которые обеспечивают ресурсосбережение и уменьшение выбросов, а также отвод излишка дилюата в цистерну дистиллята для обеспечения запаса пресной воды. Конечное значение водосодержания и солесодержания водомазутной эмульсии контролируется перед подачей ее к котлам и двигателям внутреннего сгорания.

Достигнутая таким образом максимальная активность водотопливной эмульсии с водосодержанием $\sim 30 \%$ приводит к созданию отношения $\mathrm{NO}_{2}: \mathrm{NO}$ в дымовых газах на уровне 0,33 , которое обеспечивает снижение интенсивности низкотемпературной коррозии, а также эмиссии токсичных инградиентов, благодаря интенсификации процесса абсорбции. Вследствие этого обеспечивается интенсивное поглощение $\mathrm{NO}_{\mathrm{x}}$ и $\mathrm{SO}_{2}$ конденсатом $\mathrm{H}_{2} \mathrm{SO}_{4}$ с концентрацией около $\quad 57 \%$ на конденсационных поверхностях нагрева и газоходов до скрубберной части (при обеспечении условий надежной работы их металла путем поддержания температуры стенки на уровне $\left.80{ }^{\circ} \mathrm{C}\right)$

Экспериментальные исследования показали (рис.7), что вследствие сжигания кавитационно-подготовленной водомазутной эмульсии с водосодержанием около $30 \%$ (первичный метод) обеспечивается на выходе из камеры сгорания (по сравнению с сжиганием мазута) снижение $\mathrm{NO}_{\mathrm{x}}$ в 3,2 раза (с $533 \mathrm{мг} / \mathrm{m}^{3}$ до $\left.167 \mathrm{мг} / \mathrm{M}^{3}\right), \mathrm{SO}_{2}$ в 2,5 раза (с $449 \mathrm{мг} / \mathrm{M}_{3}$ по $\left.183 \mathrm{мг} / \mathrm{m}^{3}\right)$ и $\mathrm{CO}_{2}$ в 1,4 раза от 12,2 до 8,5 об.\% в то время, как при впрыске водяных паров в зону активного горения в количестве, которое соответствует водотопливной эмульсии с $\mathrm{W}^{\mathrm{r}}=30 \%$, выбросы $\mathrm{NO}_{x}$ и $\mathrm{SO}_{2}$ более высокие.

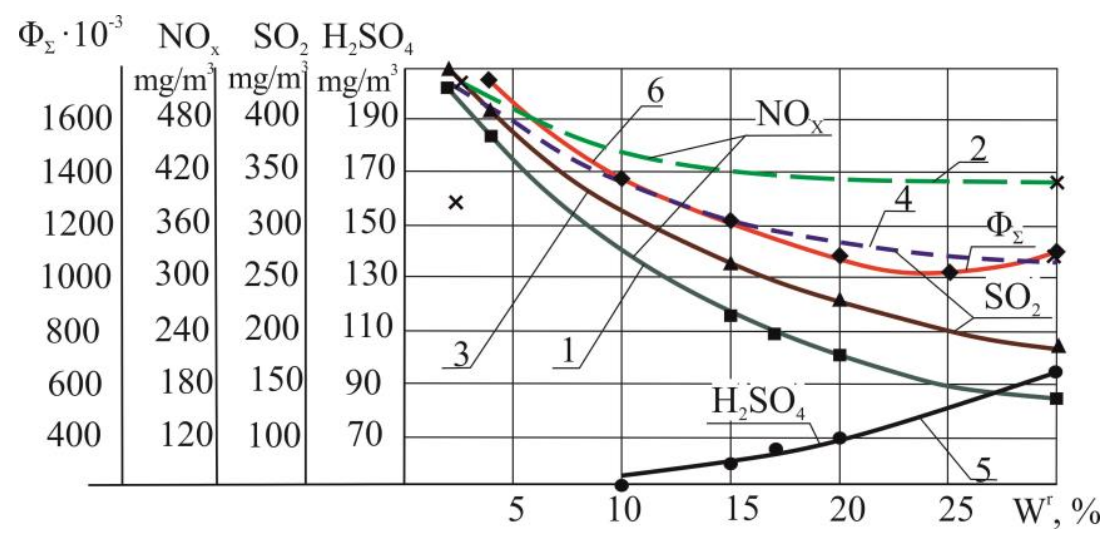

Водосодержание ВТЭ / Water content WFE

1 - водомазутная эмульсия, 2 - мазут М40 + водяной пар; 3 - водомазутная эмульсия, 4- мазут М40 + водяной пар; 5 - пары серной кислоты $\mathrm{H}_{2} \mathrm{SO}_{4} ; 6$ - суммарная токсичность $\Phi_{\Sigma}$.

Рис. 7. Зависимость эмиссии $\mathrm{SO}_{2}, \mathrm{NO}_{x}, \mathrm{H}_{2} \mathrm{SO}_{4}$ от водосодержания водотопливной эмульсии $\mathrm{W}^{\mathrm{r}}$ и способа впрыске воды (пара). ${ }^{7}$

${ }^{7}$ Appendix 1 
Вследствие улучшения абсорбционных свойств дымовых газов; размеры секции

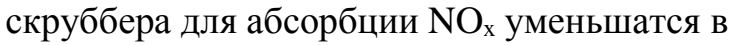
$3 . . .4$ раза, а секции абсорбции $\mathrm{SO}_{2}$, с учетом роста интенсивности абсорбционных процессов $\mathrm{SO}_{2}$ по нитрозному механизму, уменьшатся в 5..8 раз. Размеры секции абсорбции $\mathrm{CO}_{2}$ уменьшатся в 1,4 раза за счет уменьшения доли органической части водотопливной эмульсии (30\% воды и $70 \%$ мазута) (рис.8).

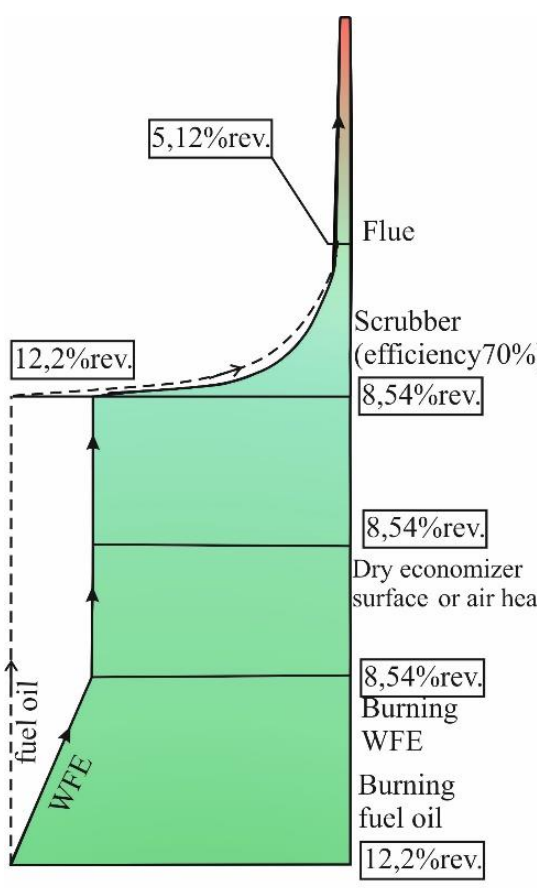

$\mathrm{CO}_{2}$

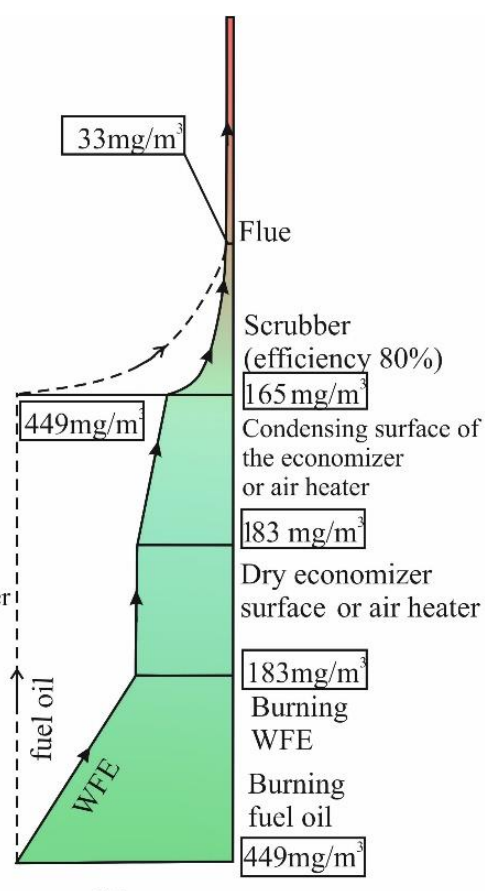

$\mathrm{SO}_{2}$

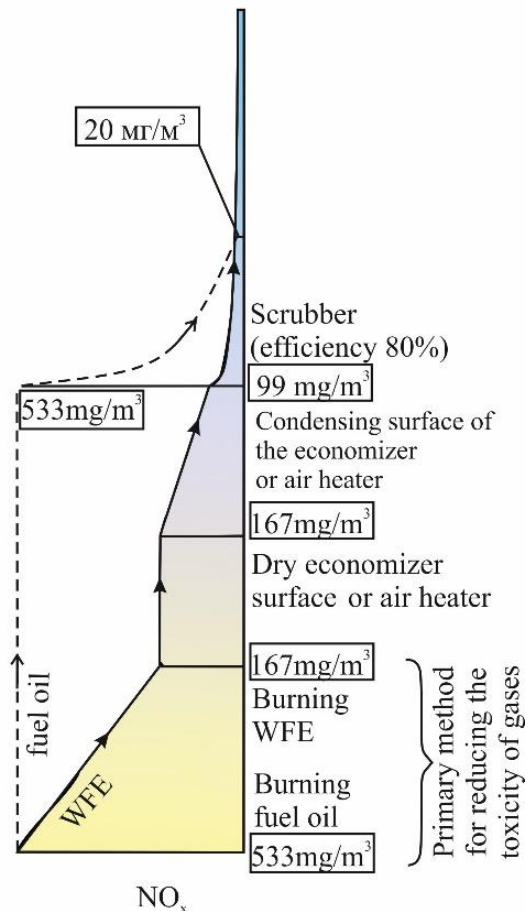

$\mathrm{NO}_{\mathrm{x}}$

Рис. 8. Снижение выбросов вредных веществ при сжигании водомазутной эмульсии с применением скрубберной технологии для котлов. ${ }^{8}$

\section{Заключение}

1. На основании проведенных экспериментальных и аналитических исследований при сжигании водотопливных эмульсий на основе мазутов при осуществлении физико-химической коррекции их состава и свойств (водосодержания от 2 до $30 \%$, солесодержания от 17 до 490 мг/дм³ кавитационной обработке, под действием сильного электрического поля в электродиализном аппарате) разработана технология комплексного использования топливно-энергетических и водных ресурсов обеспечивающая повышение техникоэкономической и экологической эффективности, а также работоспособности котлов при сжигании водомазутных эмульсий с водосодержанием $230 \%$ на основании следующих установленных показателей:

- экономии чистого топлива при горении водотопливных эмульсий в топках промышленных котлов до $25 . .27$ \%;
- необходимости поддержания активности эмульсии непосредственно перед сжиганием

(при отключенном гомогенизаторе экономия топлива снижается на $12 \%$ );

снижения интенсивности низкотемпературной коррозии до уровня $0,3 \ldots 0,12$ мм/год в диапазоне значений температуры металла $130 \ldots 70 \quad{ }^{\circ} \mathrm{C}$ при солесодержании водотопливной эмульсии $17 \ldots 490$ мг/дм ${ }^{3}$, что позволяет снизить температуру уходящих газов до $80 \ldots 100{ }^{\circ} \mathrm{C}$, повышение КПД вспомогательных котлов на $10 \ldots 15 \%$ и увеличить глубину утилизации теплоты выхлопных газов до 65\%;

- достижения в составе дымовых газов отношения $\mathrm{NO}_{2}: \mathrm{NO}$ на уровне 0,33 , что повышает абсорбционные свойства сернистых газов и приводит к пассивации углеродистой стали в конденсате серной кислоты при температурах металла в пределах $130 \ldots 70{ }^{\circ} \mathrm{C}$;

- снижения концентрации $\mathrm{NO}_{x}$ в 3,2 раза, $\mathrm{SO}_{2}$ в 2,5 раза, $\mathrm{CO}_{2} 1,4$ раза по сравнению с 
выбросами при сжигании мазута с содержанием серы $2 \%$.

2. Разработаны конструктивные схемы промышленных (отопительных) и утилизационных котлов с установкой конденсационных поверхностей нагрева (экономайзеров, воздухоподогревателя, секции горячего теплоснабжения) изготовленных из углеродистой стали при температуре стенки $\mathrm{t}_{\text {ст }}$ до $70{ }^{\circ} \mathrm{C}$, что обеспечивает конденсацию паров $\mathrm{H}_{2} \mathrm{SO}_{4}$ ), a при $\mathrm{t}_{\mathrm{cт}}$ ниже $70{ }^{\circ} \mathrm{C}$ - конденсационных поверхностей из нержавеющий стали с конденсацией паров $\mathrm{H}_{2} \mathrm{SO}_{4}$ и $\mathrm{H}_{2} \mathrm{O}$, т.к. конденсат $\mathrm{H}_{2} \mathrm{SO}_{4}$ при температуре ниже $70{ }^{\circ} \mathrm{C}$ имеет меньшую концентрацию и более активен) или вместо нее теплообменной поверхности из углеродистой стали в скрубберах при доведении $\mathrm{pH}$ орошающего раствора на выходе до уровня 6,5..7,0, что позволяет повысить КПД промышленных котлов до 99\% и выше (при расчете по низшей теплоте сгорания топлива).

3. Применение электродиализных опреснителей для получения необходимого количества воды (дилюата и католита) обеспечивает комплексное использование водных ресурсов региона: дилюата со свойствами дистиллята для подготовки водомазутной эмульсии и создания запаса пресной воды, а католита со щелочными свойствами для орошения насадки скруббера c целью обеспечения интенсификации абсорбционных процессов.

4. Повышение абсорбционных свойств уходящих газов и католита, который направляется на орошение скрубберов, позволяет уменьшить размеры секций скруббера для абсорбции $\mathrm{NO}_{\mathrm{x}}$ в 3...4 раза, абсорбции $\mathrm{SO}_{2}$ в $5 \ldots 8$ раз, а абсорбции $\mathrm{CO}_{2}$ в 1,4 раза с обеспечением современных требований к уровню выбросов токсичных веществ.

5. Разработанная технология позволяет использовать нефтемаслосодержащие и сточные воды в составе эмульсий при доведении их солесодержания до 180 мг/дм³ а также комплексное использование водных ресурсов регионов, располагающих солоноватыми, солеными и морскими водами.

\section{APPENDIX 1 (ПРИЛОЖЕНИЕ 1)}

1Fig. 1. The activity of water in the emulsion during cavitation-circulation preparation. ( 1 - maintaining a constant value of activity in the water-oil emulsion; 2 - a stable state of a water-oil emulsion (no coagulation of water droplets for a month) but no activity in terms of $\mathrm{pH})$.

${ }^{2}$ Fig. 2. Comparison of data on consumption of waterfuel emulsions $B_{W F E}$ and pure fuel $B_{\text {p.f }}$ depending on water content $\mathrm{W}^{\mathrm{r}}$ of water-fuel emulsions.

${ }^{3}$ Fig. 3. Saving pure fuel $B_{\text {p.f }}$ in emulsions depending on their water content $\mathrm{W}^{\mathrm{r}}$.

${ }^{4}$ Fig. 4. Dependences of the rate of high-temperature corrosion of steels $\mathrm{K}$ at the time of exposure to the gas flow $\tau$ equal to 100,1000 and $3000 \mathrm{~h}$.

${ }^{5}$ Fig. 5. Dependences of the rate of low-temperature corrosion $\mathrm{K}$ of steel 20 on the temperature of the metal $t_{\mathrm{cm}}$ (at $\tau=100$ hours).

${ }^{6}$ Fig. 6. Block diagram of the technology of the process of integrated use of fuel, energy and water resources.( 1,2 - block diagram of light cavitation treatment of water, 3 - electrodialysis water desalination plant, 4, 5, 6 - block diagram of heavy cavitation treatment of water and fuel, 7 - fuel tank, 8 - cavitator (homogenizer)).

${ }^{7}$ Fig. 7. Dependence of the emission of $\mathrm{SO}_{2}, \mathrm{NO}_{\mathrm{x}}$, $\mathrm{H}_{2} \mathrm{SO}_{4}$ on the water content of the water-fuel emulsion $\mathrm{W}^{\mathrm{r}}$ and the method of injection of water (steam). ( 1 - water-oil emulsion, 2 - fuel oil M40 + water vapor; 3 - water-oil emulsion, 4- fuel oil M40 + water vapor; 5 - sulfuric acid vapors $\mathrm{H}_{2} \mathrm{SO}_{4} ; 6$ - total toxicity $\Phi_{\Sigma}$ ).

${ }^{8}$ Fig. 8. Reduction of emissions of harmful substances during combustion of water-oil emulsion using scrubber technology for boilers.

\section{Литература (References)}

[1] Allaa M., Soulayman S., Abdelkarim T., Walid Z. Water/Heavy Fuel Oil Emulsion Production, Characterization and Combustion. Int. Journal of Renewable Energy Development, 2021, vol. 10, no 3, pp. 597-605. Available at: https://doi.org/10. 14710/ijred.2021.34873 (accessed 11.05.2021).

[2] Omi R.T., Yahya W.J., Abd Kadir H., Ezzat Chan A.F., Ithnin A.M., Abdullah N.R., Rahman M.M., Tahir U. Performance and Emissions of Diesel Engine with Circulation Non-Surfactant Emulsion Fuel System. Journal of Advanced Research in Fluid Mechanics and Thermal Sciences, 2021, vol. 82, no. 2, pp. 96-105. Available at: https://doi.org/10.37934/arfmts.82.2.96105 (accessed 19.05.2021).

[3] Soulayman S., El-Khatib R. The Effect of Fuel Emulsion on Fuel Saving in Fire Tube Boilers of Tartous Company for Cement and Construction Materials. Journal of Solar Energy Research Updates, 2020, vol. 7, pp. 1-6. Available at: http://dx.doi.org/10.15377/2410-2199.2020.07.01 (accessed 22.04.2021). 
[4] Sugeng D.A., Ithnin A.M., Yahya W.J., Abd Kadir H. Emulsifier-Free Water-in-Biodiesel Emulsion Fuel via Steam Emulsification: Its Physical Properties, Combustion Performance, and Exhaust Emission. Energies, 2020, vol. 13, no. 20, 5406. Available at: http://doi.org/10.3390/ en13205406 (accessed 05.05.2021).

[5] Singh G., Lopes E., Hentges N., Ratner A. [Experimental Investigation of Water Emulsion Fuel Stability]. ASME International Mechanical Engineering Conference and Exhibition 2019, Salt Lake City, Utah, USA, pp. 1-6._Available at: https://doi.org/10.1115/IMECE2019-10258 (accessed 06.05.2021).

[6] Jhalani A., Sharma D., Soni Sh. L., Sharma P.K., Sharma S. A Comprehensive Review on WaterEmulsified Diesel Fuel: Chemistry, Engine Performance and Exhaust Emissions. Environmental Science and Pollution Research, 2019, vol. 26, no. 5, pp. 4570-4587. Available at: https://doi.org/10.1007/s11356-018-3958-y (accessed 06.05.2021).

[7] Ithnin A.M., Yahya W.J. A Review on MicroExplosion Phenomena in Water-in-Diesel Emulsion Fuel. Journal of Advanced Vehicle System, 2018, vol. 5, no. 1, pp. 1-8. Journal homepage: www.akademiabaru.com/aravs.html ISSN: 2550-2212 (accessed 06.05.2021).

[8] Hsuan C.-Y., Hou S.-S., Wang Y.-L., Lin T.-H. Water-In-Oil Emulsion as Boiler Fuel for Reduced $\mathrm{NO}_{\mathrm{x}}$ Emissions and Improved Energy Saving. Energies, 2019, vol. 12, no. 1, pp. 1-8. Available at: https://doi.org/10.3390/ en12061002 (accessed 05.05.2021).

[9] Melo-Espinosa E.A., Bellettre J., Tarlet D., Montillet A., Piloto-Rodríguez R., Verhelst S. Experimental Investigation of Emulsified Fuels Produced with a Micro-Channel Emulsifier: Puffing and Micro-Explosion Analyses. Fuel, 2018, vol. 219, pp. 320-330. Available at: https://doi.org/10. 1016/ j.fuel.2018.01.103 (accessed 11.05.2021).

[10] Lin S.-L., Lee W.-J., Chang S.-S., Lee C., Lee L.-F., Lin C.-S., Loong H. Energy Savings and Emission Reduction of Traditional Pollutants, Particulate Matter, and Polycyclic Aromatic Hydrocarbon Using Solvent-Containing Water Emulsified Heavy Fuel Oil in Boilers. Energy \& Fuels, 2011, vol. 25, no. 4, pp. 1537-1546. Available at: https://doi.org/10.1021/ef200083g (accessed 11.05.2021).

[11] Nowruzi H., Ghadimi P. Effect of Water-InHeavy Fuel Oil Emulsion on the Non-Reacting Spray Characteristics Under Different Ambient Conditions and Injection Pressures: A CFD Study. Scientia Iranica, 2016, vol. 23, no. 6, pp. 26262640. Available at: https://doi:10.24200 / SCI.2016.3972 (accessed 11.05.2021).

[12] Karmakar S, Som S.K, Rao D.C.K. Combustion of Multi-Component Fuel Droplets. Droplets and
Sprays, 2017, pp. 77-114. Available at: https://doi.org/10.1007/978-981-10-7449-3 4 (accessed 11.05.2021).

[13] Da Silva M., Sad Cr. M.S., Pereira L.B., Corona R. R.B., Bassane J. F.P., Dos Santos F.D., Neto D. M.C., Silva S. R.C., Castro E. V.R., Filgueiras P.R. Study of the Stability and Homogeneity of Water in Oil Emulsions of Heavy Oil. Fuel, 2018, vol. 226, pp. 278-285. Available at: https://doi.org/10.1016/j.fuel.2018.04.011 (accessed 11.05.2021).

[14] Davidson V.V., Eliseev V.I., Tolstopyat A.P., Tolstopyat P.A. [Combustion of Water-Oil Emulsions in Thermal Units] Materialy 4-go Minskogo mezhdunarodnogo foruma po teplomassoobmenu [Materials of the 4th Minsk Intern. Heat and Mass Transfer Forum]. Minsk, 2000, vol. 10, pp. 405-412. (In Russian).

[15] Sigal A.I. Vliyanie Vlagi v Dut'evom Vozdukhe na Effektivnosnt' Raboty Kotlov Promyshlennoy i Kommunal'noy Energetiki [Influence of Moisture in the Blast air on the Efficiency of Industrial and Municipal Energy Boilers]. Teploenergetika Heat Power Engineering, 2004, no. 12, pp. 34-37. (In Russian).

[16] Dolinskiy A.A., Basok B.I. DiskretnoImpul'snaya Transformatsiya Energii v Adiabatno Vskipayushchem Potoke [Discrete-Pulse Energy Transformation in an Adiabatically Boiling Flow]. PromyshlennayaTteplotekhnika - Industrial Heating Technology, 2001, vol. 23, no. 4-5, pp. 520. (In Russian).

[17] Margulis M.A. Zvukokhimicheskie Reaktsii $i$ Sonolyuministsentsiya [Sound Chemical Reactions and Sonoluminescence]. Moscow, Khimiya, 1986, 288 p. (In Russian).

[18] Gaba A., Enescu D., Nedelcu J., Salisteanu C.I. [Reduction of Fuel Consumption and Pollutants Emissions in a Steam Boiler Using Cerium Nitrate Additive]. Recent Advances in Energy, Environment and Development [International Conference on ENERGY \& ENVIRONMENT (EE '14). Geneva, Switzerland]. 2015, pp. 27-37. Available at: https://www.researchgate.net/ publication/274634287 (accessed 11.05.2021).

[19] Kormilitsyn V.I., Lyskov M.G., Rumynskii A.A. Kompleksnaya Ekosovmestimaya Tekhnologiya Szhiganiya Vodomazutnoi Emul'sii i Prirodnogo Gaza s Dobavkoy Sbrosnykh Vod [Integrated Eco-Compatible Technology for Combustion of Water-Oil Emulsion and Natural Gas with the Addition of Waste Water]. Teploenergetika - Heat Power Engineering, 1996, no. 9, pp. 13-17. (In Russian).

[20] Sinayskiy N.A., Goshey T.A. Ispol'zovanie Tyazholoy Kavitatsii dlya Szhiganiya Mazuta i emul'sii [Using the Heavy Cavitation Method for Burning Fuel Oil and Emulsion]. Teploenergetika - Heat Power Engineering, 2003, no. 5, pp. 76-81. (In Russian). 
[21] Yakubovskiy Y.V., Sumenkov V.M., Seleznev Y.S. Ekspluatatsiya Proizvodstvennykh Kotlov KVG-34K na Vodotoplivnoy Emul'sii [Operation of Industrial Boilers KVG-34K on Water-Fuel Emulsion]. Rybnoe Khozyaistvo - Fish industry, 1991, no. 3, pp. 57-60. (In Russian).

[22] Parsadanov I.V., Teplitskiy A.A., Solodovnikov V.V., Velik S.Yu. Primenenie Vodotoplivnoy emul'sii v Avtotraktornom Dizele. Ekologicheskaya Effektivnost'. (Chast' I) [The Use of a Water-Fuel Emulsion in an Automotive Diesel Engine. Environmental Efficiency. (Part I)]. Dvigateli Vnutrennego Sgoraniya - Internal Combustion Engines, 2011, no. 2, pp. 118-120. (In Russian).

[23] Ecospec $\mathrm{CSNO}_{\mathrm{x}}{ }^{\mathrm{TM}}$ Broshure: Available at: https://www.environmental-expert.com/ downloads/ecospec-csnox-3-in-1-emissionabatement-system-brochure-785875 (accessed 04.09.2013).

[24] Landet R.D. PM Emissions and $\mathrm{NO}_{\mathrm{x}}-$ Reduction due to Water in Fuel Emulsions in Marine Diesel Engines: Norwegian University of Science and Technology, Department of Marine Technology, Student Thesis. - 2010, 73 p. Available at:

https:// hdl.handle.net/11250/237793 (accessed 04.09.2013).

[25] Kjolholt J. [Assessment of Possible Impacts of Scrubber Water Discharges on the Marine Environment]. The Danish Environmental Protection Agency (Environmental Project No. 1431 ISBN 978-87-92903-30-3)]. 2012, 93 p. Available at:

https://www.mst.dk (accessed 27.07.2021).

[26] Hansen J.P. [Exhaust Gas Scrubber Installed Onboard MV Ficaria Seaways] Public Test Report The Danish Environmental Protection Agency (Environmental Project No. 1429 ISBN 978-8792903-28-0.)]. 2012, 30 p. Available at: https:// www 2.mst.dk (accessed 27.07.2021).

[27] Amelin A.G. Proizvodstvo sernoy kisloty [Sulfuric Acid Production]. Moscow, Khimiya, 1967, 472 p. (In Russian).

[28] Statsenko V.N., Sumenkov V.N., Seleznev Yu.S. Effektivnost' Primeneniya Vodotoplivnoy Emul'sii [Efficiency of Using Water-Fuel emulsions in Ship Boilers]. Sudostroenie Shipbuilding, 1999, no. 2. pp. 31-34. (In Russian).

[29] Gorbov V.M., Goryachkin A.V. [Investigation of the Intensity of Corrosion Processes During the Combustion of Water-Oil Emulsions]. Sbornik Nauchnykh Trudov UGMTU [Collection of Scientific Papers USMTU], 2003, vol. 5, no. 391, pp. 87-95. (In Russian).

[30] Goryachkin V.Yu., Goryachkin A.V., Akimov O.V., Iutinskiy V.O., Kornienko V.S. Sposib Zakhystu Metalu Nyz'kotemperaturnykh Poverkhon' Nahrivu Kotla vid Sirchanokyslotnoi Korozii [Method of Metal Protection of Low-
Temperature Boiler Heating Surfaces from Sulfuric Acid Corrosion]. Patent UA, no. 99408, 2012. (In Ukranian).

[31] Tanaka H. Influence of Anions and Cations on the Formation of Iron Oxide Nanoparticles in Aqueous Media KONA Powder and Particle Journal, 2020, pp. 1-11. Available at: https://doi.org/10.14356/kona.2022003 (accessed 19.05.2021).

[32] Bi C., Li D., Yang X., Lu Y., Zhang J., [Prediction of Flue Gas Acid Dew Point Temperature Distribution Range in Boilers]. IOP Conf. Series: Materials Science and Engineering, 2020, vol. 721, pp. 1-10. Available at: https://doi:10.1088/ 1757-899X/721/1/012016 (accessed 27.05.2021).

[33] Stefanoni M., Angst U, Elsener B. The m

[34] Mechanism Controlling Corrosion of Steel in Carbonated Cementitious Materials in Wetting and Drying Exposure. Cement and Concrete Composites, 2020, Vol. 113, pp. 1-11.

Available at: https://doi.org/10.1016/j. cemconcomp.2020.103717 (accessed 19.05.2021).

[35] Sun R., Yu Q., Zhang Y., Yan X., Lu Y., Zhang C., Wang Q. Effect of Si Content on the Corrosion Behavior of $420 \mathrm{MPa}$ Weathering Steel. Metals, 2019,vol. 9, no. 5, p. 486. Available at: https:// doi.org/10.3390/met9050486 (accessed 19.05.2021).

[36] Shah M., Ayob M.T.M., Rosdan R., Yaakob N., Embong Z., Othman N.K. The Effect of $\mathrm{H}_{2} \mathrm{~S}$ Pressure on the Formation of Multiple Corrosion Products on 316L Stainless Steel Surface. The Scientific World Journal,2020, pp. 1-11. Available at: https://doi.org/10.1155/2020/ 3989563 (accessed 19.05.2021).

[37] Wang Y.C., Tang G.H. Prediction of Sulfuric Acid Dew Point Temperature on Heat Transfer Fin Surface. Applied Thermal Engineering. 2016, vol. 98, pp. 492-501. Available at: https:///doi.org/

10.1016/j.applthermaleng.2015.12.078 (accessed 25.05.2021).

[38] Ebara R., Tanaka F., Kawasaki M. Sulfuric Acid Dew Point Corrosion in Waste Heat Boiler Tube for Copper Smelting Furnace. Engineering Failure Analysis, 2013, vol. 33, pp. 29-36. Available at:

https://doi.org/10.1016/j.engfailanal.2013.04.007 (accessed 24.05.2021)

[39] Liu J., Gong X., Zhang W., Sun F., Wang Q. Experimental Study on a Flue Gas Waste Heat Cascade Recovery System under Variable Working Conditions. Energies, 2020, vol.13, no. 2. 324: pp. 1-19. Available at: https://doi.org/ 10.3390/en13020324 (accessed 08.06.2021).

[40] Magadeev V.Sh. Korroziya Gazovogo Trakta Kotel'nykh Ustanovok [Corrosion of the Gas Tract of Boiler Plants]. Moscow, Energoizdat, 1986, 272 p. (In Russian). 
[41] Ots A.A. Korroziya $i$ Iznos Poverkhnostei Nagreva Kotlov [Corrosion and Wear of Heating Surfaces of Boilers]. Moscow, Energoatomizdat, 1987, 272 p. (In Russian).

[42] Kurnikov A.S., Panov V.S. [Application of Water-Cut Fuels as an Energy-Saving Technology] Vestnik Volzhskoi Gosudarstvennoi Akademii Vodnogo Transporta [Bulletin of the

\section{Сведения об авторах.}
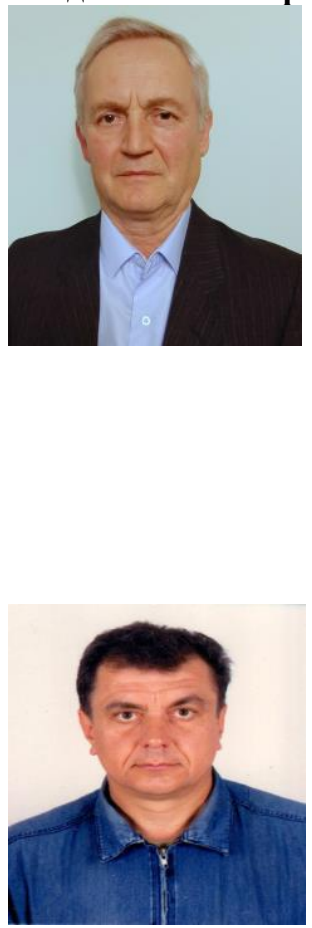

Филипщук Александр Николаевич, старший преподаватель кафедры автоматики и электрооборудования НУК им. адмирала Макарова.

Область научных интересов: энергосбережение, экология, электродиализное опреснение и очистка вод, процессы коррозии.

E-mail:

filipschuk5@gmail.com

\section{Колбасенко Олег} Васильевич, аспирант кафедры технической теплофизики и судовых паропроизводящих установок НУК им. адмирала Макарова.

Область научных интересов: энергосбережение, экология, подготовка эмульсий, процессы горения.

E-mail: orden2020@gmail.com
Volga State Academy of Water Transport]. Nizhny Novgorod, 2011, vol. 28, pp. 103-115. (In Russian).

[43] Sukhotin A.M. Fizicheskaya Khimiya Passiviruyushchikh Plenok na Zheleze [Physical Chemistry of Passivating Films on Iron]. Leningrad, Khimiya, 1989, 320 p. (In Russian).

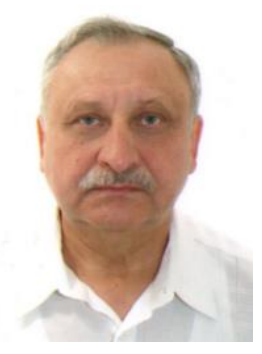

$\begin{array}{lr}\text { Шевцов } & \text { Анатолий } \\ \text { Павлович, } & \text { доктор } \\ \text { технических } & \text { наук, }\end{array}$ профессор, НУК им. адмирала Макарова.

Область научных интересов: термогазодинамическое совершенствование и экологическая безопасность энергетических установок.

E-mail: aootnet@ukr.net

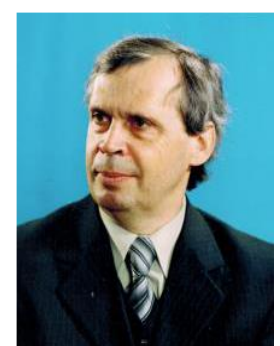

Дымо Борис

Васильевич, кандидат технических наук, профессор, заведующий кафедрой технической теплофизики и судовых паропроизводящих установок НУК им. адмирала Макарова. Область научных интересов: энергосбережение, процессы теплообмена, двухфазные термосифоны.

E-mail:

dymobv@gmail.com 